\title{
Interactive Principles in English Learning and Teaching Interaction
}

\author{
Noor Chairani \\ English Department Study Program, Faculty of Teacher Training and Education, Ahmad Dahlan \\ University, Yogyakarta \\ Chair_raini91@yahoo.co.id
}

\begin{abstract}
Communication in learning and teaching process involves interaction between teacher and learner(s) and also with their peers that will take and give inputs and feedback to each other. The activeness of learner is emphasized. However, in practice, problems still happen on domination of teacher. The teacher sometimes does not invite his/her learners to participate in learning and teaching processes. Therefore, this research will generate a theory of the interactive principles in English learning and teaching interaction. This research is on English learning and teaching interaction at the international oriented senior high school in Yogyakarta. This research was conducted based on the question: "What are the interactive principles in English learning and teaching interaction at a senior high school in Yogyakarta.

The data collection in this research used interviews and classroom observations at the school. The interviews and classroom observations were recorded and then transcribed into written data. Their statements related with interactive principles were analyzed and coded into concepts, subcategories, and categories which were related to one another. The research was qualitative study and using the grounded theory approach. The participants in this research were divided into five categories namely: a deputy principal of curriculum, two English teachers, a content course teacher, a tutor and twelve learners.
\end{abstract}

The research revealed three interactive principles in English learning and teaching interaction found from data analysis namely: unearthing comprehension, extrinsic motivation and giving autonomy to learners. The unearthing comprehension consisted of giving an explanation, doing exercises and reviewing material. The extrinsic motivation consisted of controlling learner's langua ge and relaxing atmosphere. The giving autonomy to learners consisted of creating independent learning and building learner's creativity.

Keywords: English, English Learning and Teaching Interaction, Interactive Principles

\section{INTRODUCTION}

Sapir defines that language is purely human and non-instinctive method of communicating ideas, emotions, and desires by means of a system of the voluntarily produced symbol (Sapir, 1921 in Poole, 1999:4). Language, as we know, is used as a means of communication to convey the message and to express feeling, ideas, emotions, and desires. Undoubtedly, language is needed to interact with other persons. Human has to fulfill their needs: psychologically, biologically and also spiritually, and this is done by using language as a means of communication with another human being.

English is one of the languages that is massively learned by many people in the world for many purposes. It is increasingly being used as a tool for interaction among non-native speakers in the world and it is used by more than one billion English speakers of the world. English is learned and taught in many different contexts, and in many different class arrangements which are obtained through education in formal and informal ways.

Education is an area of work through which can be hoped to improve a quality of life (Novak, 1977). One of the ways to improve the quality of life is by learning The English language as an International language. English education is an area of work in which there are some efforts to make teaching and learning English more effective and efficient in order to help the learners to apply their language and knowledge actively. Hopefully, they can use it to communicate and interact with other speakers of other countries and to participate in building the world. 
Learning and teaching English is also correlated with the phenomenon of global English (Graddol, 2006:106). Harmer noted that the reality of global or the world English (es) has caused some people to become very interested in what actually happens when it is used as a lingua franca (2007:20). Related to teaching and learning English and the phenomenon of global English Kachru (as quoted by Harmer, 2007:17) proposed circles of the world English and English proficiency. He divided into three circles namely: a) the inner circle, where English is the primary language, b) the outer circle, where English had become an official language or used as a second language and c) the expanding circle, where English is learned as a foreign language.

Considering Kachru circles, Indonesia is included in expanding the circle, which part of countries where English is taught and learned as a foreign language. It means English is used only in the certain occasion and in educated place. Because English is a means of communication and it is an instrument of communication, English is expected to develop the communicative competence in globalization era through English education in formal and informal ways.

In Indonesia, English has been already introduced to pre-school until senior high school level. Aspects of English teaching and learning process have to be evaluated in order to improve life quality in personal and also social life can be acquired immediately. Therefore, English education is considered as the gate that enables the learners to enter the mutable the world of many language cultures. The learners are expected to develop and acquire the language better and they are able to see their progress which refers to their own autonomy in communicating with other people in the world and they are able to be active "participant" in this dynamic the world.

It has been long recognized that schools play a key role in social and cultural reproduction and increases one's competence because it allows one to interact with others in various social contexts. By using a language effectively, one can gather information and build self-worth through social interactions. The ability of learners in acquiring language depends mostly on the education they receive because education is a process involving learning and teaching with a purpose to achieving certain knowledge. English as a foreign language is taught and used in a formal or nonformal institution, and thus, schools play a major role in regulating language as capital and mediating access to it.

Consequently, the English language has to be mastered by any individual in this the world in order to preserve their existence technologically, economically and socio-culturally, as well as to achieve selfactualization and self-fulfillment. English is needed as a medium of communication by any individual to prepare him/herself to participant in building a better future the world.

\section{ENGLISH LEARNING AND TEACHING INTERACTION}

As we know, English as an international language is the world-widely spoken to communicate one another in every field and also there are a lot of information served in English. Therefore, learners in schools must be able to master English in order to be capable of communicating with other people in the world and follow the new information. Because English is a foreign language which is learned in Indonesia, English learning and teaching process should be always evaluated in acquiring the language.

In learning and teaching process, interaction is one of the factors that influences the acquisition of language. The Oxford Dictionary of English (1995:621) defines the noun 'interaction' taken from the root 'interact' as 'act or have an effect on each other'. Therefore, interaction is not merely action followed by reaction, but also acting reciprocally or acting upon one another. Interaction is substantive or the core of communication. It is needed for communication because it is the collaborative exchange of thoughts, feelings, or ideas between two or more people resulting in a reciprocal effect on one another. Interaction is a key point of communication and it is what communication is all about (Brown, 2001:165).

Theories of communicative competence emphasize the importance of interaction as human beings use language in various contexts to "negotiate" meaning, or simply stated, to get an idea out of one person's head and into the head of another person (Brown, 2001:165). From the very beginning of language study, classrooms should be interactive. Through interaction, learners can increase their language from what they listen or from what they read. It can be from authentic materials or from their friends' feedback in presentation, discussions, problem-solving tasks, or dialogue journals. 
Communication in learning and teaching process involves interaction between teacher and learner(s) and also with their peers that will take and give inputs and feedback to one another. Learners receive these inputs and feedbacks from their teacher and peers that can influence their development in acquiring language. Therefore, promoting interaction among learners and between learners and teacher can be used as one of the best strategies in the English A second language (ESL) learning.

The learners will be more autonomous, self-actualized and self-fulfilled when in learning and teaching process involves them. Interaction can be implemented by teacher treatment to learners and learners to themselves. Hence, learners will cope with their reality of the world and win their competition to exist confidently in the world using a language used by people and one of the languages is English.

In learning English, interaction is very significant because of some reasons: a) only through interaction, the learner can decompose the target language structures and derive meaning from classroom events. b) Interaction gives learners the opportunities to incorporate target language structures into their own speech (the scaffolding principles). c) The meaningfulness for learners of classroom events of any kind, whether thought of as interactive or not will depend on the extent to which communication has been jointly constructed between the teacher and learners.

\section{Interactive Principles}

There are some concepts of principle as the core concept and how the interactive principles in English learning and teaching interaction occur. If we take a look at Oxford dictionary (1995:919), the principle is a basic general truth that is the foundation of something, a guiding rule of personal behavior, and a general or scientific law shown in the way a thing works. It can be defined that principle of interaction in this research is a general law that becomes the basis for interaction in English learning and teaching.

According to Rivers (1987) interactive language teaching has ten principles. Those principles are: The first principle, the student is the language learner. Second, language learning and teaching are shaped by student needs and objectives in particular circumstances. Third, language learning and teaching are based on normal uses of language, with communication of meanings (in oral or written form) basic to all strategies and techniques. Fourth, classroom relations reflect mutual liking and respect, allowing for both teacher personality and student personality in a non-threatening atmosphere of cooperative learning. Fifth, basic to use of language is language knowledge and language control. Sixth, development of language control proceeds through creativity, which is nurtured by interactive, participatory activities. Seventh, every possible medium, and modality are used to aid learning. Eighth, testing is an aid to learning. Ninth, language learning is penetrating another culture; students learn to operate harmoniously within it or in contact with it. The last, the real the world extends beyond the classroom walls; language learning takes place in and out of the classroom.

According to Brown (2001:166), interaction has several principles, they are: first, automaticity that true human interaction is best accomplished when focal attention is on meanings and messages and not on grammar and other linguistic forms. Learners are thus freed from keeping language in a controlled mode and can more easily proceed to automatic modes of processing. Second, intrinsic motivation, as students become engaged with one another in speech acts of fulfillment and selfactualization, their deepest drives are satisfied. As they more fully appreciate their own competence to use language, they can develop a system of self-reward. Third, strategic investment, interaction requires the use of strategic language competence both to make certain decisions on how to say or write or interpret language and to make repairs when communication pathways are blocked. The spontaneity of interactive discourse requires judicious use of numerous strategies for production and comprehension. Fourth, risk-taking, interaction requires the risk of failing to produce intended meaning, of failing to interpret intended meaning (on the part of someone else), of being laughed at, of being shunned or rejected. The rewards, of course, are great and worth the risks. Fifth, the language-culture connection, the cultural loading of interactive speech as well as writing requires that interlocutors be thoroughly versed in the cultural nuances of language. Sixth, inter-language, the complexity of interaction entails a long developmental process of acquisition. Numerous errors of production and comprehension will be a part of this development. The role of teacher feedback is crucial to the developmental process. Seventh, communicative competence, all of the elements of communicative competence (grammatical, discourse, sociolinguistic, and strategic) are involved in human interaction. All aspects must work together for successful communication to take place. 


\section{METHOD}

This research used a grounded theory study focuses on a process (including people's actions and interactions) related to a particular topic, with the ultimate goal of developing a theory about that process. The major purpose of a grounded theory approach is to begin with the data and use them to develop a theory. More specifically, a grounded theory study uses a prescribed set of procedures for analyzing data and constructing a theoretical model from them. The term grounded refers to the idea that the theory that emerges from the study is derived from and "grounded" in data that have been collected in the field rather than taken from the research literature. Grounded theory studies are especially helpful when current theories about a phenomenon are either inadequate or nonexistent (Cresswell, 2003).

This research focused on studying interactive principles in English learning and teaching interaction at a senior high school in Yogyakarta. This research involved 17 participants that are divided into five kinds of categories; who are a deputy principal of curriculum, two English teachers, a content-course teacher, a tutor and 12 learners at the school. In this research, the delimitation of the data is to generate a theory of interactive principles in English teaching and learning taken from one school in Yogyakarta especially at GAC classes that use ACT curriculum. It covers many data texts included from observations and interviews to get understanding deeply between the theories and the practical things in the class.

\section{DISCUSSION AND FINDINGS}

After figuring out kinds of interaction, then conceptualizing English learning and teaching interaction, all the principles below are underlined from three kinds of interaction. There were seventy-four (74) concepts from interview data and observation data. Then they have conceptualized it into several subcategories and categories which were generated through an analytical and critical process of making comparisons to highlight similarities and differences. There are seven (7) subcategories and three (3) categories of English learning and teaching interaction at the school.

Table1. Concepts, Subcategories and Categories of English Learning and Teaching Interaction

\begin{tabular}{|c|c|c|c|}
\hline No. & Concepts & Subcategories & Categories \\
\hline 1. & $\begin{array}{l}\text { Opening the class, Greeting, Guiding discussion, } \\
\text { Teacher explanation, Describing the topic by the } \\
\text { teacher, Informing the learner about the goal of the } \\
\text { day, Sharing experience, Inviting expert to meet } \\
\text { learners. }\end{array}$ & $\begin{array}{l}\text { Giving an } \\
\text { explanation }\end{array}$ & \multirow{3}{*}{$\begin{array}{l}\text { Unearthing } \\
\text { Comprehension }\end{array}$} \\
\hline 2. & $\begin{array}{l}\text { Asking learners to do exercise, Giving assignment, } \\
\text { Listening to the audio, Questioning the learner, } \\
\text { Pointing learner to answer the question, Reading, } \\
\text { Listening to the recording, Making a mistake in } \\
\text { speaking class, Displaying video, Writing an essay, } \\
\text { Creating sentence. }\end{array}$ & Doing Exercise & \\
\hline 3. & $\begin{array}{l}\text { Repeating explanation, Asking the previous lesson, } \\
\text { Paying attention to learner's speaking, Starting the } \\
\text { class by asking the question, Assessment event, } \\
\text { Evaluating the result, Pointing a learner to answer the } \\
\text { question. }\end{array}$ & Reviewing Material & \\
\hline 4. & $\begin{array}{l}\text { Leveling learners based on ability in English, Afraid } \\
\text { of mistake, Reminding from peers, Announcing } \\
\text { competency test at the beginning of semester, } \\
\text { Reminding learners to speak English, Conditioning } \\
\text { learners, Punishing who speaks in Bahasa Indonesia, } \\
\text { Teaching the passive learners exclusively, Helping } \\
\text { peer in translating word, Asking permission, } \\
\text { Correcting the task together. }\end{array}$ & $\begin{array}{l}\text { Controlling Learner's } \\
\text { Language }\end{array}$ & \\
\hline 5. & $\begin{array}{l}\text { Mixing passive learners with the confident one, Peer } \\
\text { feedback, Sharing a gift from learner to their peers, } \\
\text { Rewarding the best mark, Motivating learners, } \\
\text { Giving applause, Supporting friends, Advising } \\
\text { learner for academic and non-academic things, } \\
\text { Rewarding learners who are able to answer the }\end{array}$ & & Extrinsic Motivation \\
\hline
\end{tabular}




\begin{tabular}{|c|c|c|c|}
\hline & $\begin{array}{l}\text { question, Regarding teacher like friend, Making joke, } \\
\text { Playing game, Talking with peers, Playing music. }\end{array}$ & Relaxing Atmosphere & \\
\hline 6. & $\begin{array}{l}\text { Visiting campus, Answering the question, Being } \\
\text { silent to concentrate, Using good eye contact, gesture, } \\
\text { and intonation, Learners making a rule for } \\
\text { themselves, Looking for new vocabularies as a task, } \\
\text { Volunteering, Checking learner attendance, Making a } \\
\text { report. }\end{array}$ & $\begin{array}{l}\text { Creating } \\
\text { Independent } \\
\text { Learning }\end{array}$ & \\
\hline 7. & $\begin{array}{l}\text { Discussion, Role play, Drama, Presentation, } \\
\text { Homestay, Field trip, Outdoor class activity, } \\
\text { Changing lyric music, Making advertisement and } \\
\text { news item, English debate, Quiz, Checking opinion } \\
\text { of learners. }\end{array}$ & $\begin{array}{l}\text { Developing Learner's } \\
\text { Creativity }\end{array}$ & $\begin{array}{l}\text { Giving Autonomy to } \\
\text { Learners }\end{array}$ \\
\hline
\end{tabular}

From those seven (7) subcategories, it could be conceptualized into three (3) categories: unearthing comprehension, existing extrinsic motivation and giving autonomy to learners. Three (3) categories of interaction were interrelated and overlapped. Thus, this process could be based on the emphasizing causal relationships, and fit things into a basic set of generic relationship.

\section{CONClusion}

Interactive principles in English learning and teaching interaction at a senior high school in Yogyakarta could be generated to different principles. The analysis was done based on the interview data and classroom observation data. The interviews were done with 17 participants; one deputy principal, two English teachers, one content course teacher, one debate tutor and 12 learners from class X, XI and XII of GAC class. The classroom observations were done four (4) times at the school.

Based on the analysis, there were three (3) principles of interaction which occurred in three interactive principles of interaction were found namely: unearthing comprehension, extrinsic motivation and giving autonomy to the learner. Those principles are interrelated to one another and supporting each another. So, if one principle is not present in English learning and teaching, the class will not be interactive. It means that learners tend to be passive in the class, and teacher will dominate more whereas interaction is one of the best strategies in English A second language (ESL) learning. Then, it will affect to the attainment of learning and teaching the objective.

\section{REFERENCES}

Bates, Richard. 2011. Schooling Internationally, Globalization, Internationalisation and the Future for International School. New York: Routledge.

Brown, H. Douglas. 2001. Teaching by Principles: An Interactive Approach to Language Pedagogy, Second Edition. New York: Pearson Education Company.

Cresswell, J.W. 2003. Research Design: Qualitative, Quantitative, and Mixed Methods Approaches, Second Edition. London: Sage Publication.

Graddol, David. 2006. English Next: Why Global English May Mean the End of 'English as a Foreign Language'. London: The British Council.

Harmer, Jeremy. 2007. How to Teach English. Edinburgh: Pearson Educated Limited.

2007. The Practice of English Language Teaching. Edinburgh: Pearson Educated Limited.

Hornby, A.S. 1995. Oxford Advanced Learner's Dictionary. New York: Oxford University Press

Novak, D. Joseph. 1977. A Theory of Education. Cornell: University Press.

Poole, Stuart C. 1999. An Introduction to Linguistics. New York: Palgrave.

Rivers, Wilga M. 1987. "Interaction as the key to teaching language for communication". In a Wilga M. Rivers (ed). Interactive Language Teaching. Cambridge University Press. NY.

Thompson, Jeff. 1998. "Toward a Model for International Education” in Jeff Thompson and Mary Hayden. (Eds.) International Education Principles and Practice. Oxon: Routledge. 